\title{
Field body temperatures of the amphisbaenid lizard Blanus cinereus
}

\author{
Jose Martin, Pilar Lopez, Alfredo Salvador
}

Museo Nacional de Ciencias Naturales, José Gutiérrez Abascal 2, 28006 Madrid, Spain

\begin{abstract}
Body temperatures of Blanus cinereus recorded in the field in central Spain were positively correlated with corresponding substrate and air temperatures. Mean body temperature was $1.2^{\circ} \mathrm{C}$ higher than corresponding mean substrate temperature. Mean body temperature varied with time of day. Presence under stones during daylight hours was bimodal and seasonal variation was observed in body temperature.
\end{abstract}

\section{Introduction}

Amphisbaenians are found in tropical, temperate, and desert environments (Gans, 1967). Morphological and functional adaptations of the group have been widely studied (Gans, 1974, 1978) but many biological and ecological elements remain Unknown. While the thermal biology of lizards has been well studied there are few data available for amphisbaenians (Avery, 1982; Papenfuss, 1982). Body temperatures within the genus Blanus are unrecorded but Bons and Saint Girons (1963) made reference to activity in relation to substrate temperature.

Amphisbaenians are represented in Europe only by Blanus cinereus and this species is currently considered endemic to the Iberian Peninsula. Moroccan populations are placed in two other species, B. mettetali and B. tingitanus (Busack, 1988). Blanus cinereus is a little known species (Salvador, 1981) and the scant data available on its ecology and biology were provided by Valverde (1967), Hiraldo (1974), Mellado et al. (1975), Busack (1978) and Escarre and Vericad (1981).

In this paper we examine the thermal biology of $B$. cinereus. We present body temperatures of individuals found under stones at a site in Madrid Province, Spain, and establish the relationships between body and environmental temperatures for hourly and seasonal time periods. 


\section{Material and methods}

Study area

Field work was accomplished around Hoyo de Manzanares (Madrid Province), at an elevation of approximately $900 \mathrm{~m}$. Bioclimatically this area is placed in the upper mesomediterranean level, with a dry to subhumid ombro-climate (Rivas-Martmez, 1981, 1982). The substratum is sandy with loose granitic outcrops, and forms a typically granitic landscape. Vegetation consists of predominant stands of juniper, Juniperus oxycedrus, which represents an anthropogenically degraded state of the original evergreen oak woodland as indicated by the limited presence of some bushy evergreen oaks, Quercus rotundifolia (Rivas-Martinez et al., 1987). Secondary mediterranean scrubland is also present in the area within which Cistus ladanifer (Fam. Cistaceae), Lavandula stoechas (Fam. Labiatae) and Thymus mastichina (Fam. Labiatae) dominate, while Helichrysum stoechas (Fam. Compositae), Daphne gnidium (Fam. Thymeleaceae) and in some areas Genista hirsuta (Fam. Leguminosae) occur sporadically (Rivas-Martínez, 1979).

Predominant soils are southern brown earths (Guerra, 1968), rich in humus, but often degraded to brown ranker. Needles accumulate beneath the junipers, forming layers severed centimeters thick.

Methods

The area was visited regularly from May through August, 1988. Random routes (approx. $200 \mathrm{~m} / \mathrm{h}$ ) were followed during the day (0600-1800 h GMT) and all the stones found were lifted; all B. cinereus found under these stones were examined.

Body ( = cloacal) temperatures $(\mathrm{Tb})$ were recorded within ten seconds after lifting the stones using a digital thermometer (range $=-20^{\circ} \mathrm{C}$ to $70^{\circ} \mathrm{C}$, resolution $=0.1^{\circ} \mathrm{C}$ ). The small size of the thermometer ( $3 \mathrm{~mm}$ at the tip) allowed us to insert it into the cloaca of every specimen. To prevent alterations in $\mathrm{Tb}$, specimens were kept on the substrate by means of a wooden stick. Substrate temperatures (Ts) and air temperature (Ta) in shade at $5 \mathrm{~cm}$ above the ground were recorded at each capture site. Snout-vent length (SVL) was measured to the nearest $1.0 \mathrm{~mm}$, and specimens were released where they were caught. 
The frequency of appearance of specimens under stones in relation to search effort was recorded. Number of observations was divided by number of random routes followed in that hour.

We used one way analysis of variance (ANOVA) to evaluate differences between means, Student's t-test for comparison between pairs of means and to determine if regression slopes were significantly different from one, the Pearson r-test to evaluate levels of correlations, and the Student-Newman-Keuls test for multiple comparisons among means (Sokal and Rohlf, 1969). To eliminate effects of Ta on Ts and viceversa, partial correlation was used, and analysis of covariance (ANCOVA) was carried out to exclude the effect of covariation of the substrate and cloacal temperatures (Calvo, 1982). We selected $\alpha$ $=0.05$ as our criterion for statistical significance.

\section{Results}

Body temperatures

One hundred and two cloacal temperatures recorded in individuals found beneath stones between May and August ranged from $13.1^{\circ} \mathrm{C}$ to $29.3^{\circ} \mathrm{C}\left(\mathrm{x}=22.5^{\circ} \mathrm{C}, \mathrm{SD}=3.4\right)$. Associated substrate temperatures varied from $12.2^{\circ} \mathrm{C}$ to $29.8^{\circ} \mathrm{C}\left(\mathrm{x}=21.3^{\circ} \mathrm{C}, \mathrm{SD}=3.4\right)$ while air temperatures varied from $11.2^{\circ} \mathrm{C}$ to $31.9^{\circ} \mathrm{C}\left(\mathrm{x}=21.1^{\circ} \mathrm{C}, \mathrm{SD}=3.6\right)$. Correlations between $\mathrm{Tb}$ and $\mathrm{Ta}(\mathrm{r}=0.95, \mathrm{P}<0.001)$, and between $\mathrm{Tb}$ and $\mathrm{Ts}(\mathrm{r}=0,79, \mathrm{P}<0.001)$ were highly significant (fig. 1). Partial correlations between $\mathrm{Tb}$ and $\mathrm{Ts}(\mathrm{r}=0.87)$ and between $\mathrm{Tb}$ and $\mathrm{Ta}$ $(\mathrm{r}=0.33)$ indicated that substrate temperatures have a greater influence on cloacal temperatures ( $\mathrm{P}<0.001$, in a t-test for correlation coefficients) than do air temperatures. The slope of the regression line of $\mathrm{Tb}$ on $\mathrm{Ts}(\mathrm{b}=0.9)$ does not differ significantly from one $(\mathrm{t}=1.29, \mathrm{P}>0.05)$.

Differences between $\mathrm{Tb}$ and $\mathrm{Ts}$ varied from $-1.6^{\circ} \mathrm{C}$ to $+4.6^{\circ} \mathrm{C}$. On average, $\mathrm{Tb}$ was $1.2^{\circ} \mathrm{C}$ above $\mathrm{Ts}\left(\mathrm{SD}=1.1, \mathrm{t}=11.02, \mathrm{P}<0.001\right.$ in a $\mathrm{t}$-test for deviation from $\left.0^{\circ} \mathrm{C}\right)$. Approximately ninety per cent $(87.2 \%)$ of the cloacal temperatures recorded were between $0^{\circ} \mathrm{C}$ and $3{ }^{\circ} \mathrm{C}$ above substrate temperature and only seven body temperatures $(6.8 \%)$ were below Ts. No significant correlation was found between $\mathrm{Tb}$ and the difference between $\mathrm{Tb}$ and $\mathrm{Ts}(\mathrm{r}=-0.13,101 \mathrm{df}, \mathrm{P}>0.05)$. Snout -vent length and the difference between cloacal and substrate temperatures were not significantly correlated $(\mathrm{r}=0.19, \mathrm{P}>0.05)$. 
Individuals whose temperatures were recorded measured between 88 and $192 \mathrm{~mm}$ $\operatorname{SVL}(\mathrm{x}=152 \mathrm{~mm}, \mathrm{SD}=24 \mathrm{~mm})$. Despite individual variation at least two size classes could be distinguished. One group was of smaller size $(x=104 \mathrm{~mm}, \mathrm{SD}=8 \mathrm{~mm}$, range $=88-114$ $\mathrm{mm}, \mathrm{n}=15)$, and another was of larger size $(\mathrm{x}=160 \mathrm{~mm}, \mathrm{SD}=10 \mathrm{~mm}$, range $=138-192 \mathrm{~mm}$, $n=87)$. Body temperatures did not differ significantly between the two groups $(t=0.98$, $\mathrm{P}>0.05)$.
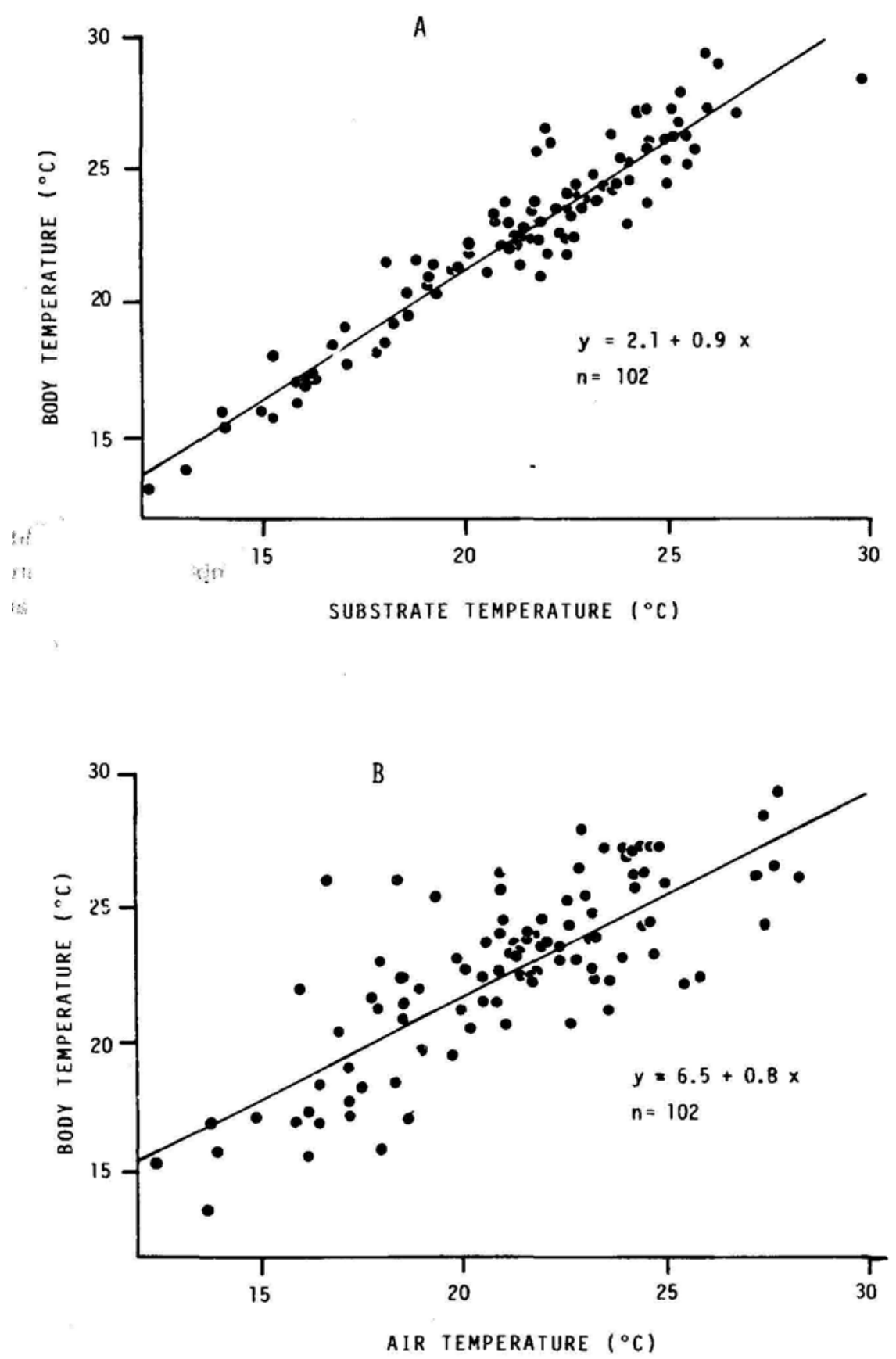

Figure 1. A: Relationship between body temperature $(\mathrm{Tb})$ and substrate temperature ( $\mathrm{Ts})$. B: Relationship between body temperature $(\mathrm{Tb})$ and air temperature $(\mathrm{Ts})$ (The regression line, equation, and sample sizes are shown in each case). 
Hourly and seasonal variation

Figure 2 shows the percentage of individuals observed, corrected for search effort, over hourly intervals. Maximum presence was noted at mid morning ( $43 \%$ of observations were made between $0900 \mathrm{~h}$ and $1100 \mathrm{~h}$ ), and another peak was seen at mid afternoon (21\% of observations were made between $1300 \mathrm{~h}$ and $1600 \mathrm{~h}$ ). B. cinereus demonstrated a bimodal activity pattern between May and August.

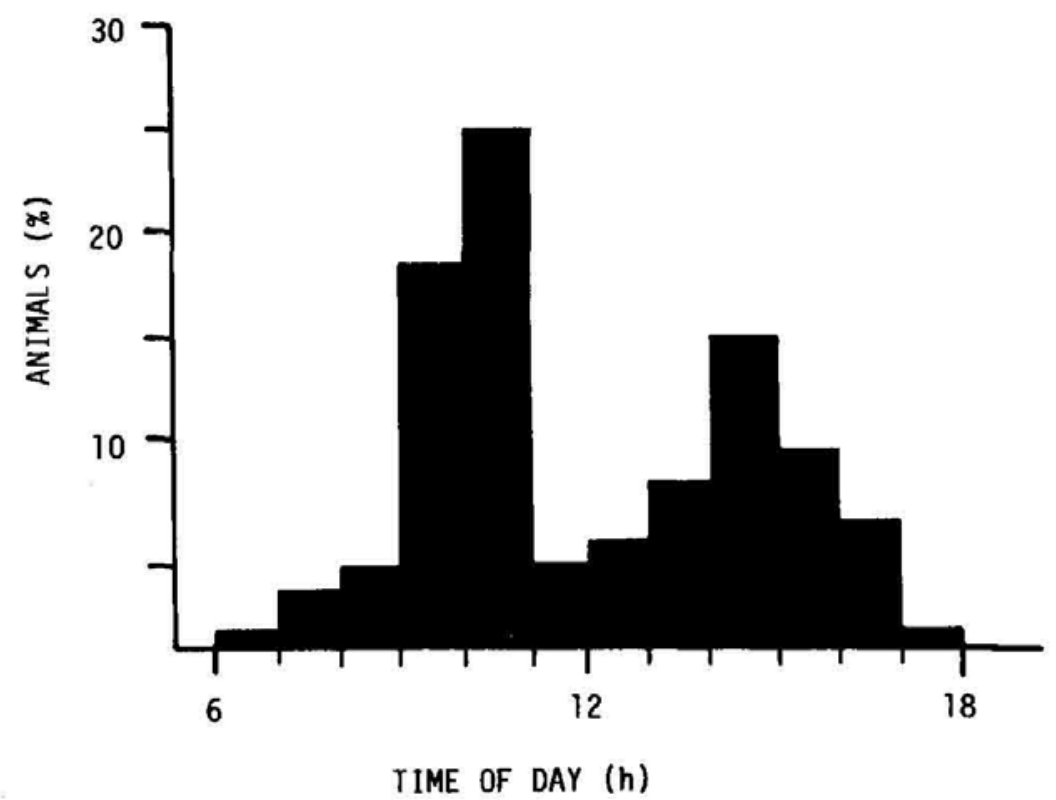

Figure 2. Percentage of individuals found under stones for each hour between 0600-1800 h (corrected for searching effort, see Methods).

Table 1. Hourly average of body $(\mathrm{Tb})$ and substrate $(\mathrm{Ts})$ temperatures $(\mathrm{x} \pm \mathrm{SE}=\mathrm{mean}$ and standard error; $\mathrm{N}=$ sample size).

\begin{tabular}{crcc}
\hline & & $T_{\mathrm{b}}$ & $T_{\mathrm{s}}$ \\
\hline HOUR & $\mathrm{N}$ & $\overline{\mathbf{x}} \pm \mathrm{SE}$ & $\overline{\mathbf{x}} \pm \mathrm{SE}$ \\
\hline $07-08$ & 4 & $22.3 \pm 0.7$ & $21.9 \pm 1.0$ \\
$08-09$ & 5 & $22.6 \pm 0.7$ & $21.3 \pm 1.4$ \\
$09-10$ & 22 & $19.6 \pm 0.8$ & $18.2 \pm 0.8$ \\
$10-11$ & 30 & $22.1 \pm 0.6$ & $20.7 \pm 0.6$ \\
$11-12$ & 5 & $23.3 \pm 0.8$ & $21.6 \pm 1.1$ \\
$12-13$ & 6 & $24.8 \pm 0.8$ & $22.7 \pm 0.8$ \\
$13-14$ & 6 & $24.5 \pm 0.7$ & $23.3 \pm 0.7$ \\
$14-15$ & 11 & $24.6 \pm 0.7$ & $23.7 \pm 0.5$ \\
$15-16$ & 7 & $25.2 \pm 0.8$ & $23.9 \pm 0.5$ \\
$16-17$ & 4 & $24.6 \pm 0.9$ & $23.3 \pm 1.1$ \\
\hline
\end{tabular}


Variation of $\mathrm{Tb}$ and $\mathrm{Ts}$ throughout the day is shown in table 1 for all the data. There was a significant variation in both $\mathrm{Tb}\left(\mathrm{F}_{11,91}=4.13, \mathrm{P}<0.001\right)$ and $\mathrm{Ts}\left(\mathrm{F}_{11,91}=4.49, \mathrm{P}<0.001\right)$. When the effect of Ts was excluded Tb still varied significantly (ANCOVA, $\mathrm{F}_{11,91}=2.11$, $\mathrm{P}<0.05)$.

When all observations were grouped into two time periods (0600-1200 $\mathrm{h}$ and 1200-1800 h), the average $\mathrm{Tb}$ between $0600-1200 \mathrm{~h} \quad\left(\mathrm{x}=21.4^{\circ} \mathrm{C}, \quad \mathrm{SD}=3.5\right.$, range $\left.=13.1-28.9^{\circ} \mathrm{C}, \mathrm{n}=67\right)$ was significantly lower $(\mathrm{t}=6.20,100 \mathrm{df}, \mathrm{P}<0.001)$ than the average $7 \mathrm{~b}$ between $1200-1800 \mathrm{~h}\left(\mathrm{x}=24.7^{\circ} \mathrm{C}, \mathrm{SD}=1.9\right.$, range $\left.=20.9-29.3^{\circ} \mathrm{C}, \mathrm{n}=35\right)$. However if the effect of is excluded, $\mathrm{Tb}$ does not differ significantly between the two periods (ANCOVA, $\mathrm{F}_{11,91}=0.52, \mathrm{P}>0.05$ ). The correlation between $\mathrm{Tb}$ and $\mathrm{Ts}$ is significant between both the $0600-1200 \mathrm{~h}(\mathrm{r}=0.96, \mathrm{P}<0.001)$ and between the $1200-1800 \mathrm{~h}$ time periods $(\mathrm{r}=0.77$, $\mathrm{P}<0.001)$. The slopes of regression lines of $\mathrm{Tb}$ on Ts between 0600 and $1200 \mathrm{~h}(\mathrm{~b}=0.95)$ and between 1200 and $1800 \mathrm{~h}(\mathrm{~b}=0.90)$ are not significantly different $(\mathrm{t}=0.65,98 \mathrm{df}$, $\mathrm{P}>0.05)$. Cloacal temperatures did not differ significantly among the different months sampled $\left(\mathrm{F}_{3,98}=0.88, \mathrm{P}>0.05\right)$ and nor did substrate temperatures $\left(\mathrm{F}_{3,98}=1.36, \mathrm{P}>0.05\right)$. However air temperatures differed significantly between months $\left(\mathrm{F}_{3,98}=6.44, \mathrm{P}<0.001\right)$ (fig. 3). $\mathrm{Tb}$ recorded between $0600-1200 \mathrm{~h}$ differed significantly between months $\left(\mathrm{F}_{3,63}=6.03\right.$, $\mathrm{P}<0.01)$ as did those recorded between 1200-1800 h $\left(\mathrm{F}_{3,68}=5.11, \mathrm{P}<0.05\right)$. Morning and afternoon $\mathrm{Tb}$ averages were significantly different in May $(\mathrm{P}<0.001$, in Student-Newman-Keuls test) and in June $(\mathrm{P}<0.001)$ but not in July $(\mathrm{P}>0.05)$. In August only a few individuals were found (5\% of the total) early in the morning (between 0700-0900 h), with $\mathrm{Tb}$ already high $\left(\mathrm{x}=22.8^{\circ} \mathrm{C}, \mathrm{SD}=1.8\right.$, range $\left.=20.5-24.8^{\circ} \mathrm{C}\right)$ and then $\mathrm{Ts}$ were also high $\left(\mathrm{x}=21.6^{\circ} \mathrm{C}, \mathrm{SD}=1.4\right)$ (fig. 4).

To study the relationship between the disappearance of individuals under stones in August and temperatures, substrate temperature was measured below stones where on other occasions amphisbaenians had been found. Between 0900-1100 h the substrate temperature recorded ranged from $24.1^{\circ} \mathrm{C}$ to $33.4^{\circ} \mathrm{C}\left(\mathrm{x}=27.4^{\circ} \mathrm{C}, \mathrm{SD}=2.4, \mathrm{n}=40\right)$, highly significantly above $(\mathrm{t}=9.61,77 \mathrm{df}, \mathrm{P}<0.001)$ the substrate temperatures in July and August when amphisbaenians were found $\left(\mathrm{x}=22.1^{\circ} \mathrm{C}, \mathrm{SD}=2.5, \mathrm{n}=39\right)$. 


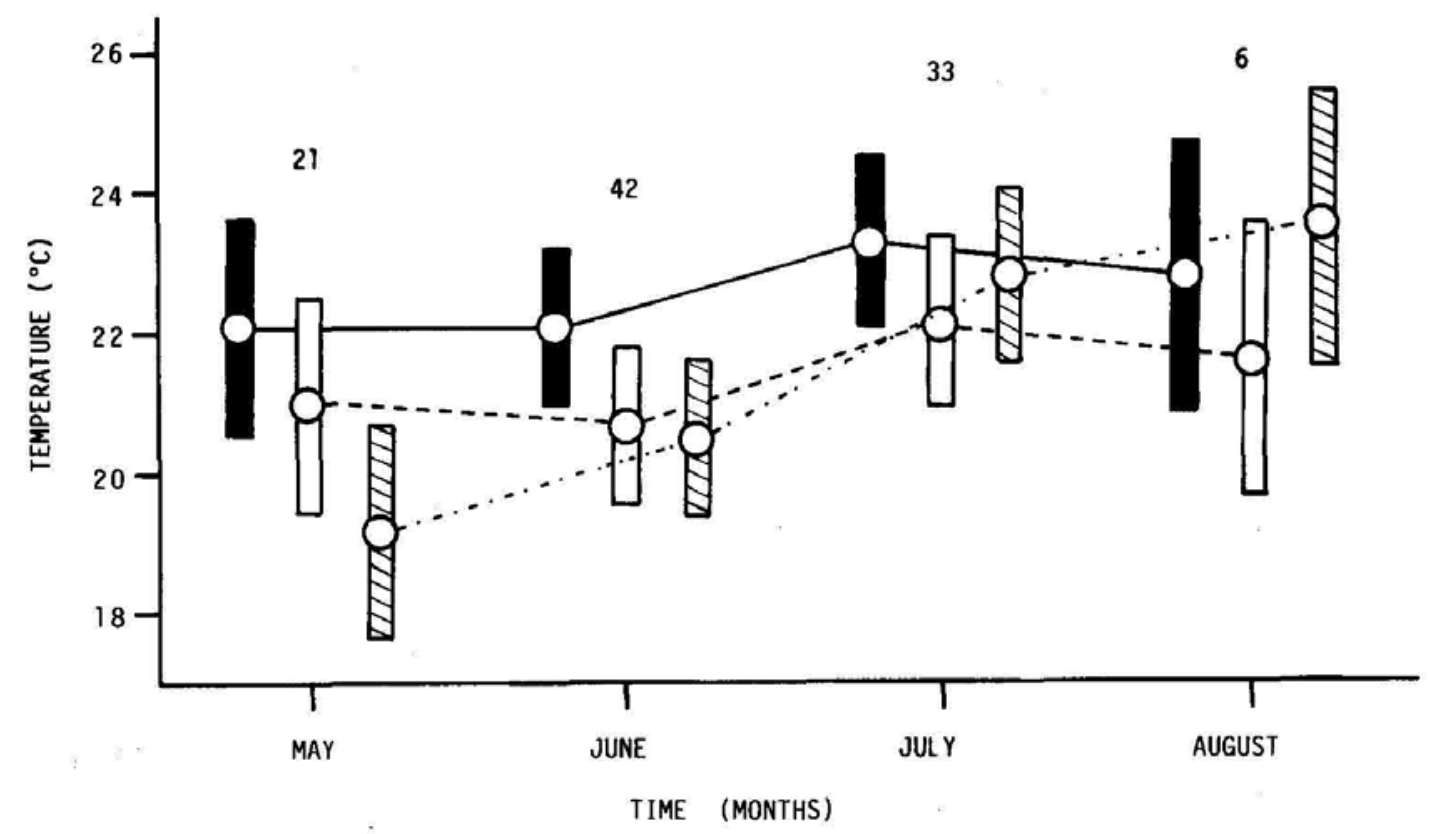

Figure 3. Monthly variation in body temperature (solid bars), substrate temperature (open bars) and air temperature (hatched bars). Mean (circle), $95 \%$ confidence limits (rectangle), and number of measurements are indicated.

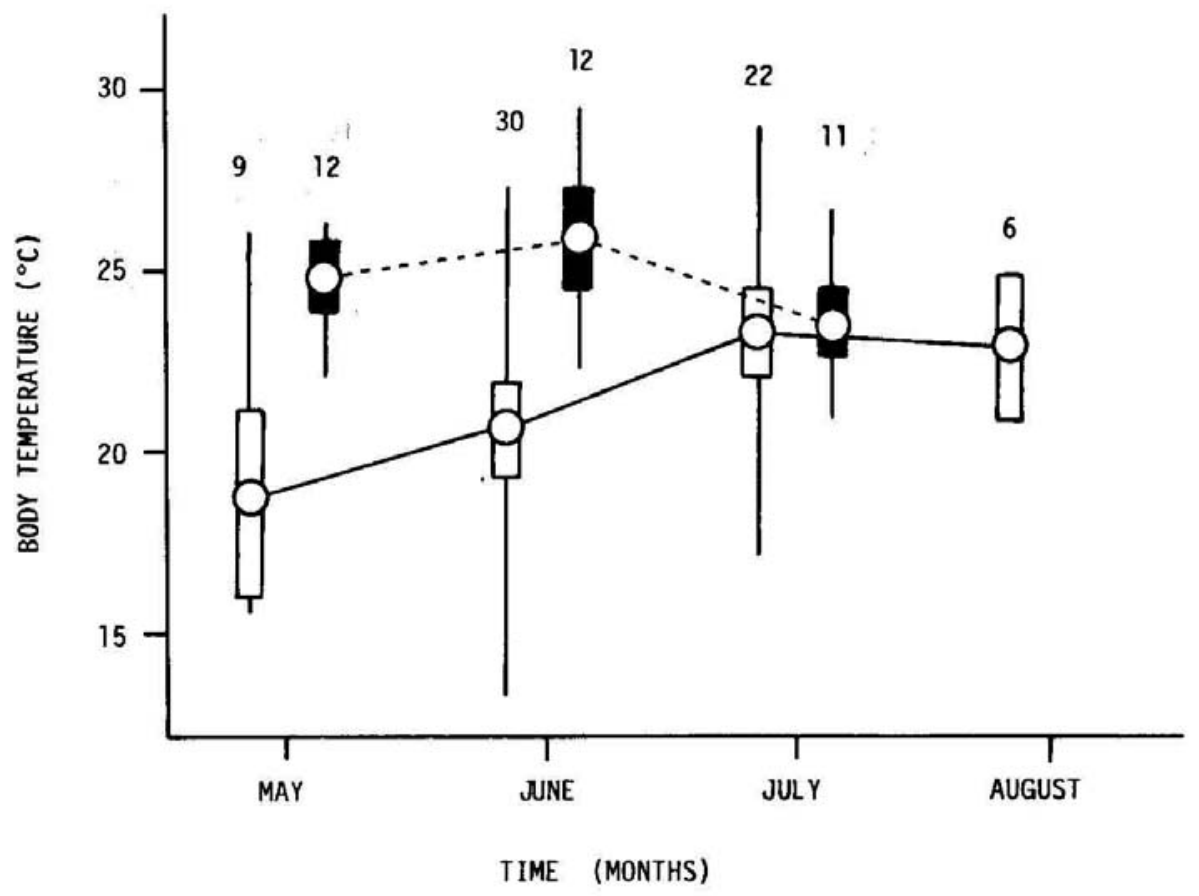

Figure 4. Monthly difference in body temperatures $(\mathrm{Tb})$ measures between 0600-1200 $\mathrm{h}$ (open bars) and between 1200-1800 h (solid bars). The range (vertical line), mean (circle), 95\% confidence limits (rectangle), and number of measurements are indicated. 


\section{Discussion}

Body temperatures of $B$. cinereus show a strong correlation with environmental temperatures. As might be expected for a species of subterranean habits, body temperatures are closely correlated with substrate temperatures, and B. cinereus seems to demonstrate a degree of thermoconformism (Huey and Slatkin, 1976). Similar situations are found in amphisbaenians of the genus Bipes (Papenfuss, 1982). The lack of correlation between the difference between body and substrate temperature (Tb-Ts) in Blanus cinereus and substrate temperature (Ts) also suggests a degree of thermoconformism (Huey and Pianka, 1977).

The relatively low range of body temperatures recorded in $B$. cinereus is similar to that recorded for other fossorial thigmothermic reptiles, such as Leptotyphlops dulcis (Clark, 1967), Anniella pulchra (Brattstrom, 1965; Bury and Balgooyen, 1976) and Anguis fragilis (Spellerberg, 1976; Gregory, 1980). On the other hand, Ophisaurus apodus, an anguid with heliothermic behaviour, achieves body temperature independently of substrate temperature (Meek, 1986). Another Mediterranean species of amphisbaenian, Trogonophis wiegmanni, demonstrates an average body temperature in the laboratory similar to that which we report for B. cinereus in the field (Gatten and McClung, 1981). Subtropical species of Bipes have body temperatures in the field somewhat higher than Blanus cinereus (Papenfuss, 1982), perhaps owing to substrate temperatures also being higher.

Provided with a thermal gradient in the laboratory T. wiegmanni shows a bimodal pattern of temperature selection during the day (Gatten and McClung, 1981). Although body temperatures of $B$. cinereus are different in morning and afternoon, this difference may be no more than a reflection of covariation between body and substrate temperature; in the hottest months the differences between body temperature in morning and afternoon become smaller.

Blanus cinereus is a typical thigmotherm that obtains the heat it needs through contact with the soil. It also takes advantage of the heat stored in the stones under which it lives. Stones often have a temperature higher than that of the surrounding environment. Thermal inertia of this type has been suggested as important to the thermoregulation of Chalcides bedriagai (Lopez Jurado et al., 1978) and Eumeces obsoletus (Hall, 1971), both ofwhich select retreats below flat stones to heat themselves. In addittion to this inertial benefit, the humidity beneath stones is high and invertebrates that shelter there could provide food for amphisbaenians (Gans, 1974). 
Daytime observations of B. cinereus under stones were bimodal. Early in the morning, many individuals were found in torpid or inactive states. As the ground warmed specimens progressively heated up, and showed an escape reflex similar to that described for $B$. mettetali (Bons and Saint Girons, 1963), by rapidly escaping along their tunnels as stones were lifted. By midday, when external environmental temperatures were high, few $B$. cinereus were observed. At this time the temperature below stones was very high and the temperature of the surronding earth more favourable, enabling individuals to move to other places. As mid-afternoon progresses, they returned to the surface below stones in lesser numbers than in the morning,

As the months became hotter $B$. cinereus reached higher temperatures sooner and showed escape reflexes earlier. In August, few amphisbaenians were observed throughout the day except those with body temperatures already high early in the morning and when substrate temperatures were already high. At other times of day the temperatures reached beneath stones were very high, perhaps above the critical temperature for this species, so activity would only be pursued deep underground. In Morocco B. mettetali disappeared in June (Bons and Saint Girons, 1963) when there is drought. The lack of soil humidity is another possible factor contributing to the absence of individuals on the surface since in the dry season the soil is very compacted (Guerra, 1968) making digging difficult for animals living underground. Similar situations are found in Uropeltid snakes (Gans, 1976).

The daytime activity rhythms of $B$. cinereus under stones suggest that, despite the fact that individuals show a degree of thermoconformism, the species has thermoregulatory behaviour tending to maintain optimal body temperatures for as long as possible by means of movements within the habitat. Possibly other amphisbaenians have similar behaviours, that contribute towards strategies aimed at compensating for the limitations of subterranean habit.

Acknowledgments. C. Gans kindly responded to our bibliographic requests. L. M. Carrascal helped us with the statistical treatment of the data and added valuable suggestions to the manuscript. This research was partially supported by CICYT (PB 88-0009). 


\section{References}

Avery, R. A. (1982): Field studies of body temperatures and thermoregulation. In: Biology of the Reptilia, 12. Physiology C. Physiological Ecology, p. 93-166. Gans, C., Pough, F. H., Eds., Academic Press,London.

Bons, J., Saint Girons, H. (1963): Ecologie et cycle sexuel des Amphisbeniens du Maroc. Bull. Soc. Sci. Nat. Phys. Maroc. 43; 117-170.

Brattstrom, B. H. (1965): Body temperatures of reptiles. Am. Midi. Nat. 73: 376-422.

Bury, R. B., Balgooyen, T. G. (1976): Temperature selectivity in the legless lizard, Anniella pulchra. Copeia 1976: 152-155.

Busack, S. D. (1978): Diurnal surface activity in the amphisbaenian Blanus cinereus (Vandelli) 1797 (Reptilia,Lacertilia, Amphisbaenidae). J. Herpet. 12: 428.

Busack, S. D. (1988): Biochemical and morphological differentiation in Spanish and Moroccan populations of Blanus and the description of a new species from northern Morocco (Reptilia, Amphisbaenia, Amphisbaenidae). Copeia 1988: 101-109.

Calvo, F. (1982): Estadistica aplicada. Ed. Deusto, Bilbao.

Clark, D. R. (1967): Experiments into selection of soil type, soil moisture level and temperature by five species of snail snakes. Trans. Kansas Acad. Sci. 70: 490-496.

Escarre,J., Vericad,J. R. (1981): Saurios y ofidios. Cuadernos de la Fauna Alicantina, 1. Inst. Est. Alicantinos, Alicante.

Gans, C. (1967): A check list of recent Amphisbaenians (Amphisbaenia, Reptilia). Bull. Amer. Mus. Nat. Hist. 135: 61-106.

Gans, C. (1974): Biomechanics: an Approach to Vertebrate Biology. Lippincot, Philadelphia.

Gans, C. (1976): Aspects of the biology of uropeltid snakes. In: Morphology and biology of Reptiles, p.191-204. Bellairs, A. D., Cox, C. B., Eds., Academic Press, London.

Gans, C. (1978): The characteristics and affinities of the Amphisbaenia. Trans. Zool. Soc. Lond. 34: 347-416.

Gatten, R. E., McClung, R. M. (1981): Thermal selection by an amphisbaenian, Trogonophis wiegmanni. J. Therm. Biol. 6: 49-51.

Gregory, P. T. (1980): Physical factor selectivity in the fossorial lizard Anguis fragilis. J. Herpet. 14: 95-99.

Guerra, A. (1968): Mapa de suelos de Espana. Inst. Nacional de Edafologia y Agrobiologia, Madrid. 
Hall, R. J. (1971): Ecology of a population of the great plain skink (Eumeces obsoletus). Univ. Kansas. Sci. Bull. 49: 357-388.

Hiraldo, F. (1974): Macroprotodon cucullatus comiendo Blanus cinereus. Dofiana, Acta Vertebrata 1: 53 .

Huey, R. B., Pianka, E. R. (1977): Seasonal variation in the thermoregulatory behavior and body temperature of diurnal Kalahari lizards. Ecology 58: 1066-1075.

Huey, R. B., Slatkin. M. (1976): Cost and benefits of lizard thermoregulation. Q. Rev. Biol. 51: $363-384$.

Lopez Jurado, L. F., Jordano, F., Ruiz, M. (1978): Ecologi'a de una poblacion insular mediterranea del Eslizón Ibérico, Chalcides bedriagai (Sauria, Scincidae). Donana, Acta Vertebrata 5: 19-34.

Meek, R. (1986): Field body temperatures of the glass lizard Ophisaurus apodus in Yugoslavia. Amphibia-Reptilia 7: 43-49.

Mellado, J., Amores, F., Parreno, F. F., Hiraldo, F. (1975): The structure of a mediterranean lizard community. Donana, Acta Vertebrata 2: 145-160.

Papenfuss, T. J. (1982): The ecology and systematics of the Amphisbaenian genus Bipes. Occ. Pap. Calif. Acad. Sci. 136: 1-42.

Rivas-Martmez, S. (1979): Brezales y jarales de Europa Occidental. Lazaroa 1: 5-127.

Rivas-Martmez, S. (1981): Les etages bioclimatiques de la vegetation de la Peninsule Iberique. Anal. Jard. Bot. Madrid 37: 251-268.

Rivas-Martmez, S. (1982): Memoria del mapa de las series de vegetacion de la provincia de Madrid. Serv. For. Med. Amb., Dip. Madrid, Madrid.

Rivas-Martmez, S., Fernandez Gonzalez, F., Sanchez Mata, D. (1987): El Sistema Central: de la Sierra de Ayllón a Serra da Estrela. In: La Vegetacion de España, p. 419-451. Peinado Lorca, M., Rivas-Martmez, S., Eds., Univ. Alcala de Henares, Madrid.

Salvador, A. (1981): Blanus cinereus (Vandelli, 1797)—Netzwuhle. In: Handbuch der Reptilien und Amphibien Europas Band 1, Echsen (Sauria) I p. 277-289. Bohme, W., Ed., Akademische Verlagsgesellschaft, Wiesbaden.

Sokal, R., Rohlf, F. J. (1969): Biometry. W. H. Freeman, San Francisco.

Spellerberg, L F. (1976): Adaptations of reptiles to cold. In: Morphology and Biology of Reptiles, p. 261-285. Bellairs, A., Cox, C. B., Eds., Academic Press, London.

Valverde.J. A. (1967): Estructura de una comunidad de vertebrados terrestres. Monogr. Est. Biol. Doñana 1, C.S.I.C., Madrid. 